\title{
Criminology Studies and Social Control Perspective to the Trend of Children Infringing Law in Indonesian Society
}

\author{
Indah Sri Utari \\ Faculty of Law, Universitas Negeri Semarang (UNNES), Indonesia \\ Email: indahsuji@gmail.com
}

\begin{abstract}
In general, the occurrence of child mischief in the community environment, closely related to the contemporary reality faced by the child. One example of a distorted child's behavior is the sexual violence committed by children to children, where the condition is much encouraged by the ease of accessing porn film (Utari 2015), so the behavior of children who deviate or violate the law is basically not entirely a child's fault, children are more victims of environmental conditions that become embryo behavior (Utari, 2012). That the same understanding with the above study of Erin Muller's study: Let the Burden Fit the Crime: Extending Proportionality Review to Sex Offenders suggests that: In 1994 and 2006, following a national dialogue about crimes against children sparked by several highprofile incidents, Congress passed two laws requiring states to register and regulate sex offenders residing within their borders. 1 States and municipalities soon caught on, and deepened restrictions. In the last five years alone, local governments have forbidden sex offenders to live within 2,000 feet of schools; $\underline{2}$ "be" within 500 feet of parks or movie theaters; $\underline{3}$ enter public libraries; $\underline{4}$ drive buses or taxis; $\underline{5}$ photograph or film minors; $\underline{6}$ and use social networking websites like Facebook (Yale law Journal V: 123 , Nomor 5, Maret 2014) Child misbehavior that occurs in various regions in Indonesia is basically also closely related to various institutions of social control, both formal and informal, which is not able to reduce the incidence of such events (Utari, 2012) Meanwhile the frequency of child mischief from time to time tend to increased, has generated much restlessness and tension in society. Through research with the approach of criminology, can reveal the background of the happening of child delinkuen behavior and the relation between social bond element to child delinquency / delinkuen, and finally will be concluded the theoretical concept of criminology which is appropriate in discussing child mischief in society. The results of this study is a knowledge that can be used as a reference for learning materials and criminology studies for the subjects of criminology course.
\end{abstract}

Keywords—social control; deviant behavior trends; criminology studies

\section{INTRODUCTION}

In fact, that the frequency of delinquency of children in the territory of Indonesia over time tends to increase, although quantitatively has not shown sharp fluctuations, but qualitatively has been worrying and menyesahkan and cause tension in society. This is reinforced when the forms of delinquent behavior have led to criminal acts such as theft, abuse, rape, extortion, drugs, street racing or inter-school brawl. That fact has become an unsettling situation in the community.

During this time the handling of deliberate behavior is often detached from the frame of correlation of social ties. When the agreement of the parties is not achieved by the handling of much use of the criminal justice process, whereas the settlement by accommodating the wishes of the parties, they get more harmony of the fair meanings they expect. Child misbehavior that occurs in various regions in Indonesia is basically also closely related to various institutions of social control, both formal and informal, which is not able to reduce the incidence of such events (Utari, 2012)

Meanwhile the frequency of child mischief from time to time tend to increased, has generated much restlessness and tension in society. As reported by (bisnissurabaya.com) - that the juvenile delinquency statistics data in Surabaya from January to November 22, 2016 total juvenile delinquency handled by the Satpol PP team of 793 cases. The details, 597 men and 196 women. This number has increased compared to 675 cases last year. In the final note of 2015, the Indonesian Child Protection Commission (KPAI) revealed that, as a whole the number of children as perpetrators in criminal cases is increasing, in the first half of 2015 violence against children reached 105 cases. (Bisniscom Jakarta 2 January 2016 at 19.15)

Delinquency of children in the community who became the object of analysis in this study is a form of delinquency performed by children who are interpreted as deviant behavior or considered to deviate by society or government. It has long been the term "child delinquency" as an instrument of articulation of the interests of various groups or even the stigma given by society or government. The facts show that the child's deviant behavior is always solved with penalties that end up as a correctional institution as a correction body. This condition is similar to some other countries as the study of Reginald Dwayne Betts in his work titled Only Once I Thought About Suicide (Yale law Journal Vol 125 January 15, 2016) which states: In 1996, when I was 
sixteen, a fifteen-year-old friend and I carjacked a man in Virginia. Shortly after being arrested, I confessed. Back then, I did not know what it meant to be transferred to criminal court. But I would learn. Following John DiLulio's super-predator theory, state prosecutors began to rely increasingly on statutory mechanisms that they transferred from juvenile to criminal court, where, if found guilty, they would be exposed to the same punishments and the same prisons as people eighteen or older. To date in Indonesia, the study of Reginald Dwayne Betts is still finding its reality. Many deviant behaviors of children are directly used penal facilities, while the review of in-depth study of the real factors that encourage the realization of behavioral deviation has not been studied clearly.

Some of the following contemporary conditions, becoming the starting point of this criminology study against the deviant behavior of children in society to be implemented. The first so far in dealing with the settlement of troubled children, many done through the means of penal by ignoring other factors that contribute to determine the control of juvenile delinquency as well as social ties that exist in society. Second There is no specific study in the perspective of criminology, understanding the correlational factors of these symptoms that are rooted in society. The third study of child delinquency with Social Control theory approach has not been much in demand where the theory emphasizes the social attachment aspect in children. The four Social Control Theory of Travis Hirschi with Attachment, Involvement, Commitment, and Belief aspects, has not been much tried to be criticized through a study of whether the theory is appropriately applied to Indonesian society with high plurality. The social controls and trends of children's deviant behavior in the criminology perspective, examining the behavioral phenomena of children who violate norms both theoretically and factually require an understanding of the needs they find difficult to obtain such as social bonding or soasial controls that can dampen their deviant behavior. In addition, this study elaborates factors that encourage deviant behavior of the child and analyzes it through social control theory which includes four aspects of Attachment, Involvement, Commitment, and Belief. So it is appropriate if the environmental conditions soasial child perpetrators of irregularities, the discovery of the factors driving the occurrence of irregularities are analyzed with social control theory.

\section{Theoretical Dimensions in Deviant Behavior}

Several studies of deviant behaviors that researchers have done, including First Model Handling Case Crime with Child Abusers in Polrestabes Semarang: Studies on the implementation of the Juvenile Justice System (Utari 2013). This study concludes that the Semarang City Resort Resort Police has implemented diversion in case handling with child abusers, but many cases are unsuccessful to be diverted due to non-agreement between the perpetrator and the victim. The Second Study on Children's Sexual Violence: The Criminology and Victimology Study of Children as perpetrators and victims in Central Java Province (Utari, 2015 ), in this study found a surprising result that $90 \%$ of the factors driving child abusers of sexual violence are their freedom to consume pornographic films on various occasions, so the real perpetrator is also the victim of the environment that exists on him. The third is a study entitled Model of Coaching in Child Correctional Institutions: A Study of the Development System of Child Development at Kutoarjo Child Development Institution of Central Java (Utari, 2017).

This ongoing study would like to see if the coaching model in LPKA will be beneficial to the targeted child and whether the system is a policy policy that is very supportive for the best interests of the targeted children. Some of the above research revolves around the disclosure of delinquency or deviant acts done by the child only related to the factors driving and handling the case, but have not touched the reality and the dynamics or trends of contemporary deviance of the child and have not analyzed it by using Social Control theory approach with emphasis on the aspect of attachment social in children. The Social Control Theory of Travis Hirschi encompasses Attachment, Involvement, Commitment, and Belief, which aspect of such aspects is fundamental to the relationship of so-called attachment. In the absence of such aspects as a result, there is no comprehensive model, concept and picture in the criminological perspective on deviant behavior undertaken by children with the dynamics, and current deviant behavior trends and their implications in Indonesian society. This study can fill the void, in addition to highly relevant to the current reality of deviant behavior carried out by children getting higher in society.

The basic concepts of criminology are thrilled and subject to change as antithetical to the political, economic and social conditions of the 1960s. As Western criminologists generally take the instruments of the state as their reference-group, the theories, analyzes and explanations are confined within the limits of the practical problems of the official means of control in order to serve them (Utari, 2012: 24). Meanwhile, Prof.'s view Sahetapy argues that in the perspective of criminology a symptom in society should be analyzed with a criminology blade that refers to sociocultural, structural or spiritual conditions. (Sahetapy 2005: 42) This sobural approach was raised by J.E. Sahetapy recalls the social values, cultural aspects, and structural factors, elements that are contained in every society that comes with the emergence of evil. Cultural aspects and structural factors are two elements that influence each other in society. Therefore, both elements are dynamic in accordance with the dynamics in the society concerned. (Sahetapy 2005: 52) According to F. Ivan Nye (1988) human beings are given control so as not to commit violations, therefore adequate (adequate) socialization process will reduce the happening of delinkuensi. Because, here is the process of education of a person who is taught to perpetuate restraint of desire (impulse). In addition, internal and external factors of control must be strong, as well as with law-abiding. This is where control theory begins to elaborate in explaining the phenomena present in society. The most reliable and highly popular social theory is put forward by Travis Hirschi (Utari, 2012: 113) 
Hirschi asserted that a behavior is caused by the absence of attachment or lack of attachment (moral) perpetrators to society. Control theory or often also called Social Control Theory departs from an assumption or the assumption that the individual in society has the same tendency to be "good" or "evil". The good of a person is totally dependent on the people. He becomes good when society makes it so, he becomes evil when society makes it so. According to Travis Hirschi, there are four elements of social bonds in every society. (M.R. Gottfredson, and Travis Hirschi 1987: 11)

First, attachment is the human ability to involve itself against others.

If this attachment has been formed, then the person will be sensitive to the thoughts, feelings and desires of others. The attachment link to deviation is the extent to which the person is sensitive to the thoughts, feelings and desires of others so that he can freely make a deviation. Attachments are often interpreted freely with attachments. The first bond is the attachment to the parents, the attachment to the school (teacher) and attachment with peers.

Second, commitment is one's attachment to conventional subsystems such as school, work, organization and so on. Commitment is a rational aspect of social bonding. Any activities that a person undertakes such as school, work, activities in the organization will benefit the person. These benefits can be property, reputation, future, and so on. Third, involvement is one's activity in the subsystem. If a person plays an active role in the organization, there is little tendency to deviate. The logic of this understanding is that if the person is active in all activities then he will spend time and energy in the activity. So, he did not have time to think about things that were against the law. Thus, any activity that may benefit will prevent the person from committing acts contrary to law. Fourth, belief is a moral aspect contained in social ties and certainly different from the three aspects above. Belief is one's belief in moral values. One's belief in existing norms leads to adherence to the norm. Compliance with the norm will certainly reduce the desire to violate. However, if people do not comply with norms then it is more likely to commit a violation. The relationship between Attachment and Commitment is often stated to tend to be reversed in reverse. According to research on delinkuen, one of the "problems" of teenagers from the lower classes is that he is unable to break his attachment to parents and peers. The attachment that prevents it from devoting enough time and energy to educational and work aspirations. (Hagan, 2007: 79) Symptoms of child delinquency behavior in Indonesia, although quantitatively have not shown sharp fluctuations, but qualitatively have been concerned about society. (Herndroyono, 2015: 62) As we know that adolescence is a period of unstable. Where at that moment arises the sense of wanting to show myself "this is me". Therefore, the attitude of imitating among children or adolescents is a tendency during puberty. (Abdussalam, 2007: 29) This means that if they can not control themselves well and if leisure time can not be utilized as well as possible, then the action of fun and other delinquency is very easy to happen. As well as skipping school during school hours, drug abuse and its modified forms are quite symptomatic among younger ages and the way in which clothing is excessive and inappropriate to use can ultimately lead to free sex and consequently many teens get married in their teens. While the forms of delinquent behavior that lead to criminal acts such as theft, abuse, rape, extortion, drugs, street racing or brawl between schools in the event indicate kejagoannya, also shows symptoms that are not different. Symptoms involving the behavior of children / adolescents lately stand out in the community. Teenagers with all the traits and value systems often lead to behaviors that people respond to that should not be done by teenagers. Such behaviors appear both in the form of ordinary delinquency and behavior that leads to crime. Masyarakatpun directly or indirectly become anxious to face these symptoms. On the basis of these descriptions, the importance of this research is conducted.

\section{Perspective of Deviant Behavior}

Deviant behavior can be seen through the Perspective of Conventional Criminology and New Criminology Perspective of Conventional Criminology This perspective was influenced by influential positivism flows in the nineteenth century. Some of the characteristics of conventional perspectives that stand out about crime are: 1) The emphasis of attention on the perpetrators of irregularities or perpetrators of "crime." 2) The size of deviant or not an act is determined by the values and norms that are considered as the value orientation by those who occupy positions of power or authority. This kind of criminology is based on the rules whose offenses are referred to as aberrations. The rules are taken for granted, regarded as absolute and undisputed. Regarding the deviance much studied from sociology so that it is a branch of study in the department of sociology in a faculty. 3) The view that deviant behavior as a social process occurs on certain social environmental influences either through the learning process or as a result of social reactions with consequences which may be in the form of circumstances that bring about evil or defamation. In this case often utilized Sutherland's theory of Differential Asociation Theory and Crime and Social Processes. 4) The effort of social control over the behavior of irregularities is important to restore adherence to values and norms. This effort is usually sectoral, for example as described in the analysis to strengthen the family's social control function or improve the function of primary soci-aliza- tion. Some socio-logical observers recommend it in terms of restructuring. 5) The law is deemed to come later from such an act of "evil" or deviant to prevent and protect the community from the act. This assumption was accepted without criticism

\section{New Criminology Perspective}

Through the works of the authors who spawned the perspectives of criminology in the 1960s, they looked at the key issues analyzed to gain input on matters of crime and / or deviant behavior: 1) The emphasis is more on the consequences and social reactions of behavioral aberrations in society. 2) The deviant measure of an act is determined not by the values and norms deemed legitimate by those who 
sit in positions of power or authority, but by the greatest loss or social suffering caused by such acts and reviewed in the context of the inequality of power and prosperity in society. Thus, the values and social norms are questioned. The formulation of crime in criminology is increasingly expanded. The target of attention is primarily directed at the politically, economically and socially damaging crimes that result in casualties, not just individual sacrifices but societies. When this is open the eyes of the public that there are other crime patterns than conventional ones are nonconventional like White Collar Crime, Corporate Crime and others. 3) Deviant behavior as a social process is considered to be a reaction to upper class life. Uncertainty of justice. 4) Social control efforts are placed within the framework of reducing structural inequality, which means plunging you into the deepest interests of the people. 5) Criminal policy as part of social policy that is national development so criminology insight broaden and clear target. As the Differential Theory Association proposed by Edwin $\mathrm{H}$. Sutherland, an American sociologist in his book Principles of Criminology (1934). Where the assumptions in this theory are influenced by William I. Thomas and George Mead who are symbiancial interactionism, also the ecological flow of Clifford R. Shaw and Henry D. McKay, and Culture Conflict from Thorsten Sellin. There are two versions of the theory of Differential Associations. The first version is in the third edition of Principle of Criminology. In the work Sutherland's attention is focused on cultural conflict, social disorganization, and differential associatioan.

Three points as the essence of the theory:

a. Any person can be trained to adopt and follow any pattern of behavior which he is able to execute. (each person will accept and follow the behavioral patterns that can be implemented).

b. Failure to follow a conscious harmony in the influences which direct the individual. (failure to follow a behavioral pattern (which should) lead to inconsistencies and disharmony).

c. The conflict of cultures is therefore the fundamental principle in the explanation of crime. (cultural conflict is a basic principle in explaining crime). Furthermore, Edwin H. Sutherland defines the Differential Association as "the contens of the patterns presented in association".

This does not mean that only intercourse with criminals will lead to criminal behavior, but the most important is the content of the communication process of others. 1947 Edwin H. Sutherland presents a second version of the Differential Association theory which emphasizes that all behavior is learned, nothing derived from the inheritance of parents. Strictly speaking, the pattern of evil behavior is not inherited but learned through an intimate association. To that end, Edwin H. Sutherland then explains the 9 paths of the process of crime or deviant behavior: (1) Evil behavior is learned. Sutherland suggests that the behavior is not inherited so there can be no mechanically evil people; (2) Evil behavior is learned from others in a process of interaction; (3) The most important part of the evil behavior that is learned, is obtained in a group of intimate associations; Thus, instantaneous and insedental interpersonal communication, has no important role in the learning process of the crime. (4) When the behavior of the crime is learned, the fingerprinting is (a) how to commit the crime both difficult and simple, (b) special guidance on motives, rationalizations, attacks, and attitudes; (5) Specific guidance on motives and scenarios is learned from the interpretation of the law; In a society, sometimes someone is surrounded by people who simultaneously see what is stipulated in the rule of law as something that needs to be observed and obeyed, but sometimes surrounded by people who see the rule of law as something that provides opportunities for the commission of a crime). (6) A person becomes delinquent because of the excesses of thinking patterns that see the rule of law as an evil-doing opponent rather than seeing the law as something to be observed and obeyed). (7) Differential Associations vary in frequency, duration, priority and intensity). (8) The process of studying evil behavior is gained through a connection with crime patterns and mechanisms that are prevalent in every learning process in general. (9) Although evil behavior is a reflection of common needs and values, the criminal behavior is not explained through the common needs and values, because non-criminal behavior is a reflection of common needs and values.

\section{Social Control and Child Deviant Behavior}

Trends The nature of social control is seen from the process include: Preventive (prevention), Rrepressive (fixing) and combined Judging from the amount of coverage involved 1. supervision of individuals against other individuals 2. supervision of individuals against the group 3. insight from the group against group 4. control of the group against individuals. Seen from the aspect of its implementation include 1.Persuasif (non-violence) 2. Coersif (compulsion) 3. Compulsive, that is creating a situation that can change attitude or behavior of negativity and someone forced to obey from situation which deliberately created controller 4. Pervasi that is value and norms are conveyed or inserted repeatedly and continuously in the hope of being embedded in the soul of a person so that will form the expected attitude. Deviant behavior may occur as a result of inappropriate co-ordinating processes. The process of socialization can be considered unsuccessful if the individual is not able to deepen the norms of society to be part of himself. The process of socialization experienced by an imperfect person is caused by the media of information and socialization media that one with another contradict each other. Sometimes messages submitted by socializing agencies such as family, playmates, school, and mass media are not equivalent or conflicting with one another. For example: a family giving a message to not smoke to family members in this case is abak, but the child saw or read in the media how cigarettes are advertised with great interest. He also saw his playmates all smoking. This circumstance causes the child to experience an inner conflict between respecting the norms or values that the family provides or choosing the norms that develop in the playgroup. The process of imperfect socialization can also arise due to 
defects in the suffering since the birth of mental disorders, mental disorders and so forth.

In the perspective of theory, the most reliable and highly popular social theory is put forward by Travis Hirschi (1969). Hirschi, with the expertise of revising previous theories of social control, has provided a clear picture of the concept of social bond. Travis Hirschi agrees with Durkheim and believes that one's behavior reflects various views of morality. Hirschi argues that a person is free to commit a crime or deviation of his behavior. In addition to using neutralization techniques to explain these behaviors, Hirschi also asserted that the behavior is caused by the lack of attachment or lack of attachment (moral) perpetrators against the community. Control theory or often also called Social Control Theory departs from an assumption or the assumption that the individual in society has the same tendency to be "good" or "evil". The good of a person is totally dependent on the people. He becomes good when society makes it so, he becomes evil when society makes it so. This basic question is related to the deterrent elements that can counteract the emergence of delinkuen behavior among members of society, especially the youth, "why do we obey and obey the norms of society" or "why we do not do deviations?" According to Travis Hirschi, there are four elements of social bonds in every society. First, attachment is the human ability to involve itself against others. If this attachment has been formed, then the person will be sensitive to the thoughts, feelings and desires of others. The attachment link to deviation is the extent to which the person is sensitive to the thoughts, feelings and desires of others so that he can freely make a deviation. Attachments are often interpreted freely with attachments. The first bond is the attachment to the parents, the attachment to the school (teacher) and attachment with peers. Second, commitment is one's attachment to conventional subsystems such as school, work, organization and so on. Commitment is a rational aspect of social bonding. Any activities that a person undertakes such as school, work, activities in the organization will benefit the person. These benefits can be property, reputation, future, and so on. Third, involvement is one's activity in the subsystem. If a person plays an active role in the organization, there is little tendency to deviate. The logic of this understanding is that if the person is active in all activities then he will spend time and energy in the activity. So, he did not have time to think about things that were against the law. Thus, any activity that may benefit will prevent the person from committing acts contrary to law. Fourth, belief is a moral aspect contained in social ties and certainly different from the three aspects above. Belief is one's belief in moral values. One's belief in existing norms leads to adherence to the norm. Compliance with the norm will certainly reduce the desire to violate. However, if people do not comply with norms then it is more likely to commit a violation.

The relationship between Attachment and Commitment is often stated to tend to be reversed in reverse. According to research on delinkuen, one of the "problems" of teenagers from the lower classes is that he is unable to break his attachment to parents and peers. The attachment that prevents it from devoting enough time and energy to educational and work aspirations. According to stratified research, a boy free of this attachment is more likely to move to an upper class. Both traditions of research thus state that people who are bound to conformity due to instrumental reasons are less likely to be bound by conformity on the basis of other emotional reasons. If unbounded people are compensated for lack of attachment based on commitment to achievement and if those who do not do turn out to be tied up with people, we can conclude that neither attachment nor commitment will be linked to crime. The clearest link between the elements / elements of commitment and involvement appears in commitments in education and employment and involvement in conventional activities. We can attempt to show how commitment limits a person's opportunity to commit a crime and thus is kept away from the assumption of many control theories that such opportunities are simply and randomly distributed through the required population. The last elemental connection of social control theory is between Attachment and Belief, that there is a more or less direct relationship between attachment to another and a belief in the moral validity of the existing rules. Control theory has a number of weaknesses and advantages. The weakness is oriented to: 1 . this theory seeks to explain juvenile delinquency and not crime by adults; 2 . this theory has paid considerable attention to attitudes, desires and behaviors which, although distorted, are often adult behavior; 3. Social bonds in Hirschi theory such as values, beliefs, norms and attitudes are never clearly defined; 4. failure to explain the probability of events that resulted in the social bond not more. While the power of social control lies in aspects: 1. this theory can be tested empirically by many scholars like Wiatrowski, Griswold and Roberts; 2. social control theory is one of contemporary theories that have a strong appeal in terms of encouraging meaningful studies. Here is the reality that the child's deviant behavior can be the result of the socialization process of subcultural values of deviant. A child raised in an environment who considers drunkenness, brawls, and prostitution as a matter of course tend to do similar acts of simulation. On the other hand, according to the size of the wider community, the act is considered perverse. Dismantling comes from different associations learned through the process of cultural transfer. Through this learning process, children absorb a subculture deviate from a particular group or environment in society. From the results of research that in society there are forms of social deviation that can be categorized: primary deviation and secondary deviation. 1. Primary deviation This deviation is temporary or temporary, because it is only done once or at any time even tends not to happen again. And people who practice this deviant behavior are usually still acceptable to their social group or society because they are only temporary and usually will not be done again. For example do not use a helmet when driving on the highway and so forth.

Primary deviation features: a. Temporary b. His lifestyle is not dominated by deviant behavior c. People still tolerate the violations that occur. 2. Secondary deviations Secondary deviation is a continuous and continuous social repetition despite sanctions being given to it. So the perpetrators of these irregularities are generally known as deviant behavior ornags. For example: murder, rape, drunks, 
permapok and so forth. Secondary deviation features: a. His lifestyle is dominated by deviant behavior. b. Society can not tolerate such deviant behavior. Based on the number of perpetrators, deviant behavior can be divided into several: a. Individual irregularities, irregularities perpetrated by an individual by carrying out actions that deviate from the prevailing norms. For example: stealing a chicken that is done alone. b. Group deviations, disputes that dilakuakn in groups by taking actions that deviate from the norms applicable. For example: groups of robbers, crime gangs or mobsters. While by its nature, deviant behavior can be divided into two namely: a. Positive deviation Positive deviation is a deviation that has a positive impact because it contains elements of innovative, creative, and enrich the alternative. Thus, positive deviation is a deviation that leads to the coveted social values, although the way it does seem to deviate from the prevailing norm. For example, due to economic pressure, a housewife is forced to work as a truck driver, as a bus conductor, as a taxi driver and so forth. $b$. Negative deviations Negative deviations are deviations that tend to act toward social values that are seen as low and bad. In this negative deviation, the acts committed will be denounced by the public and the perpetrators can not be tolerated by the public. For example, gambling, theft, prostitution, and others. In the research yielded data that the form of trends of deviant behavior are: 1. Crime. That is behavior that violates the law and violates social norms so that society opposes it. Mislanya: murder, theft, persecution, corruption, kidnapping and others. Crime or crime is neither a birth-taking nor a biological heritage. Some scholars emphasize forms of processes such as imitation, the implementation of the social role of differential association, compensation, identification, self-concept and aggressive disappointment as processes that cause a person to become a criminal. Crimes can be committed by both men and women, children and adults. E.H. Sutherland argues that evil behavior is learned in interaction with others and the person gets malicious behavior as a result of his interaction with those who behave in a manner that is against the existing legal norms. Crime types include: a. White collar crime (white collar crime) is a crime committed by employers or officials in carrying out the role of its function. This group considers itself immune from the law and other means of social control, because of its strong financial power. For example: corruption. b. Blue Collar Crime is a crime committed by low strata. For example: stealing a neighbor's mango. c. Organized crime is a crime committed by a group of criminals who continually make various ways to earn money or power by avoiding the law. For example: prostitutes. d. Crime Without Victim (crime without Victim) is a crime that does not cause suffering to the victim as a result of someone else's crime. For example: gambling and getting drunk. e. Coorporate crime is a crime committed on behalf of the organization for the purpose of raising profits or suppressing losses. For example: a company that dumps toxic waste into the river and causes the inhabitants to experience various types of diseases. 2. Gambling Besides that, deviant behavior can take the form of gambling. Gambling is a deliberate gamble that is risking one value or something that is considered valuable by being aware of certain risks and expectations on game events, matches, competitions and events that are not or are not certain of the outcome. At first gambling was a form of free time filler games for the mneghibur heart but gradually added with money as a bet. The forms of gambling include the dady game, bridge card and dominoes.

There are several ways to cope with gambling, among others: a. Making a comprehensive national economic improvement, b. Provide healthy places of entertainment and recreation, and c. Prohibition of gambling practices accompanied by preventive and repressive measures (penalties and sanctions) consequently.

Sex Behavior beyond marriage The results also obtained data that behavior deviant to form of sex behavior outside of marriage. Sexual behavior outside of marriage or adultery is an act that violates the rules and must be subject to sanctions. One form of sex outside of marriage is prostitution or prostitution. According to professor W.A. Bonger, prostitution is a social phenomenon in which women sell themselves by doing sexual acts as their livelihood. As for which can be included in the category of prostitution, among others: a. Concubinage is the life of husband and wife without marriage bond b. A happy tante (Loose Married Woman) is a married woman but still having sex with other men. c. Bar girl, the girl who works as a barman while providing sexual services to the visitors. In addition, there are also some forms of sexual deviation such as homosexuals who have same-sex relationships, necrophilia that is to have sex with a dead person, pedophilia is to have sex with children as victims, Transvetitism yaity satisfy the desire of sex by wearing clothes of the opposite sex and ekshibisionisme namely sex kepauasan by showing his genitals. Sexual behavior outside of marriage and mutual couples can lead to some dampk for the individual include: a. Cause venereal disease b. May cause sexual dysfunction $c$. Destructive of family honor d. And so forth. 4. Drug Abuse Initially some narcotics and illegal drugs used by the medical community in an attempt to reduce the pain excessive experienced by patients. However, the drug eventually became a drug because it was used by people who deviate. Drug abuse is more prevalent in adolescents because of their unstable emotional development and tend to want to try something, anxious conditions, unharmonious family situations, wrong friends, and so on. Examples of illicit drugs are narcotics (marijuana, opium, putaw), psychotropic (ecstasy, magadon) and alcohol.

Deviation In The Lifestyle Form This deviation is more to an attitude of arrogance or pride to something it has such as wealth, power, and intelligence. Arrogant attitude can be done by someone who wants to cover kekurnagan himself. In social life there is always a means of social control or a means of control to control the behavior of the members of the proficiency within conformist boundaries. This means that human behavior is always limited in the range between what is allowed and what not to do. This limit is certainly in the form of commands and prohibitions. Command and prohibition on human behavior is called social control. Bruce J. Cohen (in Setiadi, 2011: 252), points out that "Social control is the means used to encourage a person to conform to the will of a particular group or society. 
Joseph S. Roucek (in Setiadi, 2011: 252) limits the "social control of all processes, whether planned or unplanned which is educational, inviting, or even compels citizens to obey the prevailing social norms and values". In line with Roucek, Setiadi (2011: 253) provides limits "Social control is a planned or not planned and supervised means and processes aimed at engaging, educating, and even forcing citizens to comply with the norms and social values prevailing within their group". From these various limitations, it can be interpreted that social control is all the way or process of supervision that is educating, encouraging, or even forcing students to obey the rules and social values to encourage students to behave in harmony with the will of certain groups of people. Social control is closely related to values and norms. For society, social norms contain hope that is used as a guide to behave. Social control is a mechanism for preventing the occurrence of irregularities and directing members of society to act according to institutional norms and values

If social controls are not implemented, then irregularities and other immoral acts are possible. Setiadi (2011) divides the characteristics of social control into two, namely: a. Preventive social control The nature of preventive control is all forms of social control in the form of prevention of deviant behavior (deviation) so that social life remains conducive (conformist). The conformist state of social life will only be achieved if social behavior is under control. Thus, the precautionary measure is the possibility of violation of prevailing social norms. b. Repressive social control Social repressive control is a form of social control aimed at restoring social disorder or restoring a deviation situation to a conducive (conformist) state. Thus, repressive social control is a form of control in which social aberrations have occurred and then returned to the social situation to return to normal. That is a situation in which society abides by social norms. (Setiadi, 2011: 255-256) Preventive social control is performed before deviations occur in order to prevent the occurrence of deviant behavior. Preventive social control can be an appeal, coaching and socialization by the parties concerned. Repressive control is the control performed after the irregularities occur. Repressive control is more widely used by society. Repressive social control is usually followed by the imposition of sanctions for the perpetrators of social aberrations. For example, a student who violates school rules or discipline, the student is subject to sanctions for school order to be re-established. Maryati (2001) classifies the types of social controls to prevent deviant behavior, among others, as follows. Rumors (gossip). Rumors (rumors) are rumors (rumors). This news is spread quickly and sometimes not based on fact or reality. The truth of the news is still in doubt. Gossip as a form of social control can make the offender aware of his actions and return to behavior in accordance with the norms in his society. This will make the actor act more cautiously and not repeat his actions. Warning. Warning is a warning directed against a person who committed irregularities. Strikes can be spoken or spoken. The purpose of reprimand is to get the offender to realize the mistake he or she has made. Strike in formal organization is done gradually. Usually a reprimand is done three times in writing. If reprimand after reprimand is ignored, then the offender will be subject to disciplinary sanctions. Punishment (punishment). Punishment is a negative sanction given to someone who violates written or unwritten rules.

Education is a social control that has been institutionalized both in the family environment and community environment. Education leads one to be responsible and useful for religion, the nation and its people. School education not only teaches knowledge and skills, but also disciplines to be disciplined and orderly in community life.

Religion is the guide of life to achieve happiness in the world and the Hereafter for its adherents. Therefore, a person embracing a religion is required to carry out its obligations and stay away from the prohibitions set out in its religious teachings. If a person believes in and obeys his religion, then by itself the behavior will be controlled from the form of deviant behavior. Physical abuse. This action is actually the last alternative in social control if other alternatives are not implemented. (Maryati, 2001: 113-114) Of the various types of controls mentioned above, more control is used in schools in control of deviant behavior that is reprimand and punishment. Where the teacher gives a reprimand when students do deviations and punishments when teachers find students caught doing aberrant behavior. There are various ways of social control so that members of society behave in harmony with the values and norms that exist in the community. The ways of social control are by way of persuasive and coercive (Muin, 2006: 171). The persuasive way emphasizes the effort to invite or guide community members to act in accordance with the rules or norms prevailing in society. It emphasizes the cognitive (knowledge) and affective (attitude) values. Coercive means are social controls that emphasize actions or threats that use physical strength. The purpose of this action so that the abuser and not do it again. However, these methods are very dangerous because violence / coercion will cause a negative response either directly or indirectly (Muin, 2006: 171). Because, if solving problems with violence will result in a lot of violence as well.

Every one of our society always finds members deviate. Likewise also deviations can occur in schools conducted by troubled students. Horton and Hunt (1984: 65) states, "Behavior is any behavior that is expressed as a violation of the norms of community groups". A person who has violated the norms in society is also called a deviant behavior. Further, Setiadi (2011: 188) states, "deviant behavior is basically all human behavior done both individually or in groups are not in accordance with the values and norms applicable within the group ". As for Bruce J. Cohen (in Muin, 2006: 153), "limiting deviant behavior as any behavior that does not conform to the will of a particular society or group in society". Regarding self-adjustment, Fatimah (2008: 194) defines "Adjustment is a natural and dynamic process aimed at changing the behavior of individuals in order to have a relationship more suited to their environmental conditions". That is, when deviators can adjust to the values and norms that apply, then the harmony will be created. From the understanding of the experts above, can be interpreted that deviant behavior is all human 
behavior that violates the rules, values and norms in a community group because it can not adjust to the will of the community group. Distorted acts, both primary and secondary, do not just happen but evolve over a period of time and also as a result of a series of interaction stages involving interpretations of agreements to act deviant. Distorted experiences are also supported by weak selfcontrol and loose community control. In an institution such as a school, students are said to be distorted if they do not obey the discipline in school. As for Asmani (2012) states forms of deviant behavior that occur in school include: a) long hair for boy students, b) Polish hair, c) Skin tone, d) Smoking, e) Fighting, f) Stealing, g) Destructive his bike / motorcycle h) free sex, i) not going to school, j) often skipping, k) no discipline, 1) crowded in class (noisy, m) Playing PS on the hour lessons, and n) Dirty classrooms and school pages (Asmani 2012: 106-121)

\section{Conclusion}

Behavior is a behavior or behavior committed by a person or group of people who violate the norms, values and norms that apply in the community which resulted in disturbances of public order and security. This behavior is generally caused because the individual or group can not absorb the values and norms into him, so he can not distinguish which behaviors are appropriate and which behavior is inappropriate to do.

\section{REFERENCES}

[1] Abdussalam, H.R., 2007 Kriminologi, Jakarta : Restu Agung

[2] Asmani, Jamal. 2012. Kiat Mengatasi Kenakalan Remaja di Sekolah (Cetakan 1) Yogyakarta : Buku Biru

[3] Betts, Reginald Dwayne. 2016, Only Once I Thought About Suicide Yale law Journal Vol 12515 Januari 2016

[4] Frank P. William III dan Marilyn McShane. 2008,
Criminological Theory, New Jersey Printice hall, Englewood Cliffs

[5] Geertz, Clifford, 1973, The Interpretation of Culture, New York: Basic Books, Inc.

[6] Hendrojono, 2015 Kriminologi: Pengaruh Perubahan Masyarakat dan Hukum, Surabaya: Srikandi

[7] John Hagan 2007 Modern Criminology : Crime, Criminal Behavior and Its Control, Singapura : McGraw Hill Book Com,

[8] M.R. Gottfredson, and Travis Hirschi (eds). 1987, Positive Criminology Newbury Park: Sage Publication

[9] Morgan, D.L.,2011 Focus Groups as Qualitative Research, London: Sage Publications.

[10] Miller, Erin. 2014 Let the Burden Fit the Crime: Extending Proportionality Review to Sex Offenders Yale law Journal Vol 123 Number 5 Maret 2014

[11] Sahetapy, J.E., 2005. Pisau Analisis Kriminologi, Bandung: Citra Aditya Bakti

[12] Utari, Indah Sri. 2012. Aliran dan Teori dalam Kriminologi Yogyakarta: Thafa Media

[13] ------------------- 2012, Masyarakat Dan Pilihan Hukum Semarang: Sanggar Krida Aditama

[14] ------------------ 2013. Model Penanganan Perkara Tindak Pidana dengan Pelaku Anak di Polrestabes Semarang : Studi terhadap penerapan Sistem Peradilan Anak ( Penelitian Tahun 2013)

[15] ---------------------2015. Kekerasan Seksual Yang Dilakukan Oleh Anak Terhadap Anak: Kajian Kriminologi dan Victimologi tentang Anak sebagai pelaku dan korban di Wilayah Propinsi Jawa Tengah ( Penelitian Tahun 2015)

[16] ------------------. 2017. Law Enforcement And The Weak Dimensions Of Victims: A criticism of the Indonesian Criminal Justice System International Journal of Business, Economics and Law Vol. 12, April 2017

[17] Straus, A dan J. Carbin, 2000, Basic Qualitative Research: Grounded Theory Procedure and Techniques, London: Sage Publication. 